\title{
ИЗМЕНЕНИЕ СОДЕРЖАНИЯ МАКРО- И МИКРОЭЛЕМЕНТОВ ПРИ САХАРНОМ ДИАБЕТЕ 2-ГО ТИПА
}

\author{
О.В. Мариинская ${ }^{1,2}$, Т.В. Казакова ${ }^{1,2}$, С.В. Нотова ${ }^{1,2}$, М.К. Молчанов ${ }^{3}$ \\ ${ }^{1}$ Федеральный научный центр биологических систем и агротехнологий РАН, г. Оренбург, Россия \\ ${ }^{2}$ Оренбургский государственный университет, г. Оренбург, Россия \\ ${ }^{3}$ Стоматологическая клиника ООО «Максидент», г. Оренбург, Россия \\ *e-mail: m.olja2013@yandex.ru
}

РЕЗЮМЕ. В течение более десятка лет наблюдается растущий интерес к роли микроэлементов в развитии и прогрессировании сахарного диабета. Дисбаланс элементов в организме может служить одним из пусковых механизмов развития патологических расстройств, ответственных за возникновение нарушений обмена и связанных с ним заболеваний. В связи с этим целью исследования было оценить изменения уровня макро- и микроэлементов в сыворотке крови у пациентовс сахарным диабетом 2-го типа. В исследовании приняли участие мужчины, средний возраст которых составлял 60 лет $(n=50)$. Оценка элементного статуса осуществлялась посредством изучения химического состава волос методами ИСП-АЭС и ИСП-МС в лаборатории АНО «Центр биотической медицины» (Москва). Для подтверждения данных анамнеза было проведено исследование показателей глюкозы и гликированного гемоглобина. Наблюдалась тенденция к более низкому уровню Са, Fe, I, $\mathrm{Co}, \mathrm{Cr}$ и более высокому уровню Se у пациентов с сахарным диабетом.

КЛЮЧЕВЫЕ СЛОВА: микроэлементы, сахарный диабет 2-го типа.

\section{CHANGES IN THE CONTENT OF MACRO-AND TRACE ELEMENTS IN TYPE 2 DIABETES MELLITUS}

\author{
O.V. Marshinskaia ${ }^{1,2 *}$, T.V. Kazakova ${ }^{1,2}$, S.V. Notova ${ }^{1,2}$, M.K. Molchanov ${ }^{3}$ \\ ${ }^{1}$ Federal Research Centre of Biological Systems and Agrotechnologies RAS, Orenburg, Russia \\ ${ }^{2}$ Orenburg State University, Orenburg, Russia \\ ${ }^{3}$ Dental clinic «Maxident», Orenburg, Russia \\ *e-mail: m.olja2013@yandex.ru
}

\begin{abstract}
For more than a decade, there has been a growing interest in the role of trace elements in the development and progression of diabetes. The imbalance of elements in the body can serve as one of the triggers for the development of pathological disorders responsible for the occurrence of metabolic disorders and associated diseases. In this regard, the aim of the study was to evaluate changes in the level of macro- and microelements in the blood serum of patients with type 2 diabetes mellitus. The study involved men with an average age of 60 years $(n=50)$. The assessment of the elemental status was carried out by studying the chemical composition of the hair using the methods of ICP-NPP and ICPMS in the laboratory of the ANO "Center for Biotic Medicine" in Moscow. To confirm the anamnesis data, a study of glucose and glycated hemoglobin parameters was performed. There was a tendency for lower levels of $\mathrm{Ca}, \mathrm{Fe}, \mathrm{I}, \mathrm{Co}, \mathrm{Cr}$ and higher levels of Se in patients with diabetes mellitus.
\end{abstract}

KEYWORDS: trace elements, type 2 diabetes mellitus.

\section{ВВЕДЕНИЕ}

В последнее десятилетие наблюдается растущий интерес к роли микроэлементов в развитии и прогрессировании сахарного диабета 2-го типа (Król, et al., 2019). Дисбаланс элементов в организме может служить одним из пусковых механизмов развития патологических расстройств, ответственных за возникновение нарушений обмена и связанных с ним заболеваний (Dubey, Thakur, 2020).

Цель работы - оценка изменения уровня макро- и микроэлементов в сыворотке крови у пациентов с сахарным диабетом 2-го типа.

\section{МАТЕРИАЛЫ И МЕТОДЫ}

В исследовании приняли участие мужчины, средний возраст которых составлял 60 лет $(n=50)$. В ходе исследования было сформировано две группы: контрольная (условно здоровые пациенты, $n=15$ ) и 
основная (пациенты с сахарным диабетом в анамнезе, $n=35$ ). Оценка элементного статуса осуществлялась посредством изучения химического состава сыворотки крови методами ИСП-АЭС и ИСП-МС в лаборатории АНО «Центр биотической медицины» (Москва). Для подтверждения данных анамнеза было проведено исследование показателей глюкозы и гликированного гемоглобина. Обработка полученных данных выполнялась при помощи методов вариационной статистики с использованием статистического пакета «StatSoft STATISTICA 10». Применялись непараметрические процедуры обработки статистических совокупностей ( $U$-критерий Манна-Уитни).

\section{РЕЗУЛЬТАТЫ И ОБСУЖДЕНИЯ}

Показатели глюкозы натощак и гликированого гемоглобина составляли 5,0 ммоль/л и 5,4\% в контрольной группе и 9,5 ммоль/л и $8,3 \%$ - в основной группе. По ряду клинических и лабораторных характеристик было установлено, что в группе с сахарным диабетом 2-го типа наблюдалось достоверное увеличение индекса массы тела на $16,5 \%(p<0,01)$, частота встречаемости артериальной гипертонии на $208 \%(p<0,01)$, триглицеридов на $57,8 \%(p<0,05)$.

Выявлено, что изучаемые микроэлементы сыворотки крови находились в пределах нормальных значений, исключение составил Со, уровень которого отмечен ниже нормальных значений $(p<0,05)$ в группе пациентов с сахарным диабетом. Уровни $\mathrm{Fe}$ и I были достоверно ниже в основной группе относительно контрольной на $19 \%(p<0,05)$ и $12,3 \%(p<0,05)$ соответственно. Наблюдалась тенденция к более низким значениям $\mathrm{Ca}, \mathrm{Cr}$ и более высоким значениям $\mathrm{Se}$ в группе пациентов с сахарным диабетом.

\section{ВЫВОДЫ}

Полученные результаты согласуются с данными других исследований, подтверждающими, что химические элементы могут играть значительную роль в развитии диабетических состояний и прогрессировании ряда метаболических осложнений (Siddiqui et al., 2014; Zhang et al., 2017).

Тем не менее требуются комплексные исследования, необходимые для выяснения четкой взаимосвязи между нарушениями метаболизма глюкозы и уровнями содержания микроэлементов.

\section{Список литературы / References}

1. Król E., Bogdański P., Suliburska J., Krejpcio Z. The Relationship between Dietary, Serum and Hair Levels of Minerals (Fe, Zn, $\mathrm{Cu}$ ) and Glucose Metabolism Indices in Obese Type 2 Diabetic Patients. Biol Trace Elem Res. 2019; $189(1): 34-44$.

2. Dubey P., Thakur V., Chattopadhyay M. Role of Minerals and Trace Elements in Diabetes and Insulin Resistance. Nutrients. 2020; 12(6): 1864.

3. Zhang H., Yan C., Yang Z., Zhang W., Niu Y., Li X., Qin L., Su Q. Alterations of serum trace elements in patients with type 2 diabetes. Journal of Trace Elements in Medicine and Biology. 2017; 40: 91-96.

4. Siddiqui K., Bawazeer N., Joy S.S. Variation in Macro and Trace Elements in Progression of Type 2 Diabetes. Scientific World Journal. 2014; 2014: 461591. 